\title{
K-Pop Merchandise Store \\ (Perencanaan Pendirian Usaha Menjual Barang-barang Ikon Idol Korea)
}

\author{
Irena Puspi Hastuti ${ }^{1}$, Erfan Effendi ${ }^{2}$, Anita $^{3}$ \\ Universitas Islam Riau ${ }^{1,2,3}$ \\ e-mail: irenpuspihastuti@eco.uir.ac.id, effendierfan@eco.uir.ac.id, \\ anitanita@student.uir.ac.id
}

\begin{abstract}
Abstrak: Yeobo store adalah perencanaan usaha dibidang merchandise K-Pop yang memproduksi dan menjual barang Official yang di produksi oleh agensi idol tersebut maupun barang Unofficial yang di produksi sendiri atau dari supplier yang menjual barang tersebut. Yeobo Store ini memiliki keunggulan dalam menjalankan usahanya yaitu dengan membuat Id Card sebagai tanda pengenal konsumen dan memiliki keistimewaan dengan memberi potongan harga setiap pembelian barang official. Kami melakukan promosi untuk produk kami melalui media elektronik berbasis Facebook, Instagram,Line, Whatsapp. Kami juga melihat potensi dalam bisnis ini dari unsur keunggulan pasar, sebab lima tahun terakhir ini K-Pop sangat mendunia hingga menjadi globalisasi budaya termasuk di Indonesia sendiri. Kegandrungan akan musik KPop membawa dampak tersendiri bagi penggemarnya sehingga banyak pihak menjadikan ini sebagai peluang bisnis yang sangat besar baik dibidang Fashion,Kecantikan maupun Industrial. Berdasarkan hasil analisis kelayakan usaha,maka dapat disimpulkan bahwa bisnis merchandise Yeobo Store dinyatakan layak untuk dijalankan dan memiliki peluang usaha yang sangat besar baik dimasa yang akan datang.
\end{abstract}

Kata kunci : Merchandise K-Pop, Barang official dan Unofficial,Budaya K-Pop

Saat ini perkembangan zaman semakin hari semakin modern diiringi dengan perkembangan teknologi yang semakin pesat. Hal tersebut diikuti dengan perkembangan media sosial dan internet yang dapat memeudahnkan beberapa orang mengakses informasi saling berkomunikasi,dan dapat mengetahui dunia luar tanpa berkunjung ke Negara tersebut.

Perkembangan teknologi informasi khususnya media massa memberikan dampak yang sangat besar dalam kemajuan komunikasi,teknologi yang canggih tidak hanya dapat menyebarkan informasi dengan cepat namun bermanfaat dalam memudahkan penyebaran informasi mengenai budaya dari seluruh dunia.

Korea Selatan menjaadi salah satu Negara yang mempopulrkan budaya pop saat ini. Aktor dan aktros serta musisinya yang berhasil "menyihir" berbagai kalangan. Budaya K-Pop pun menjadi mendunia termasuk kuliner dan budayannya. K-pop kepanjangannya Korean Pop ("Musik Pop korea") adalah jenis music populer yang berasal dari Korea Selatan. Banyak artis dan kelompok music pop Korea sudah menembus batas dalam negeri dan populer di manca Negara.

Berbagai produk budaya Korea mulai dari drama,film,lagu,fashion,gaya hidup produk-produk industry mulai mewarnai kehidupan masyarakat di berbagai belahan dunia. Budaya 
Korea berkembang begitu pesatnya dan meluas serta diterima public sampai menghasilkan sebuah fenomena demam Korean Wave (Simbar,2016).

Gelombang Korea atau Korean Wave saat ini sudah bukan lagi sesuatu yang asing di Indonesia. Penyebarannya bukan hanya melalui tayangan drama-dramanya (K-Drama) saja tetapi juga melalui musik yang dikenal dengan sebutan Korean-Pop (K-pop), fashion (Korean Style) serta peralatan elektronik dan gadget.

Industri musik dan film Korea mampu memasuki pasar musik dunia, maka dari itu budaya K-pop tak hanya dikenal secara lokal tetapi sudah secara global. Demam K-pop sudah mulai memasuki Negara kita Indonesia dari sejak tahun 2005 hingga sekarang, hal inilah yang menjadi salah satu faktor menjamurnya penggemar K-pop di Indonesia. Tak hanya muda-mudi saja yang gemar, tetapi rentang umur dewasa hingga tua pun ada yang menyukai K-pop

Remaja merupakan masa transisi atau peralihan dari masa anak menuju masa dewasa. Individu mengalami berbagai bentuk perubahan. Remaja juga berubah secara kognitif dan mulai mampu berpikir abstrak seperti orang dewasa. Remaja mulai melepaskan diri secara emosional dari orangtua dalam rangka menjalankan peran sosialnya yang baru sebagai orang dewasa, Clarke-Stewart \& Friedman; Ingersoll (dalam Agustiani, 2006: 28).

Dalam hal ini remaja mengembangkan identitasnya sebagai kelompok penggemar K-Pop yaitu K-Popers. K-Popers remaja biasanya saling menceritakan idolanya satu sama lain dan bertukar informasi, gosip hingga koleksi musik dan video terbaru. Hal ini dilakukan oleh agar mereka memperoleh eksistensinya dalam kelompok K-Popers karena mereka merasa K-Popers adalah sebagai identitas dirinya.

Manajemen K-Pop artis menciptakan official merchandise atau barangbarang yang berkaitan dengan idola masing-masing seperti album, lightstick, handuk, photobook dan kostum yang dipakai oleh sang artis. Akhir-akhir ini juga banyak entertainment yang berlomba-lomba mengadakan audisi pencarian bakat secara global. Audisi pencarian bakat ini tidak hanya diselenggarakan di Korea saja tetapi di beberapa negara, salah satunya adalah Indonesia.

Di Indonesia sendiri mulai bermunculan toko-toko secara online karena keterbatasan biaya dan jarak yang jauh untuk mendapatkan produk yang asli dari Korea. Seringkali pasar Indonesia sendiri menjual unofficial merchandise atau barang-barang replika, seperti t-shirt dan kostum-kostum para idola yang dikenakannya dipanggung. Bukan hanya atribut-atribut KPop saja yang dijual tetapi pasar juga memasuki beberapa produk kecantikan, kesehatan, makanan dan minuman khas Korea bahkan barang elektronik maupun gadget yang ikonnya adalah artis Korea atau bisa jadi produk fashion yang dipakai oleh artis-artis Korea yang banyak diminati oleh K-Popers. 
Toko Yeobo adalah sebuah toko dimana menjual barang yang bertema Korea atau yang lebih dikenal dengan nama K-Pop dan menjual berbagai macam barang dimulai dari CD/DVD Original import dari Korea Selatan serta menjual juga T-Shirt, Poster, Pin, Light Stick/Fan Light, Tas, Handuk, Masker, Kalender dan juga banyak aksesoris lainnya.

Toko Yeobo sesuai dengan namanya, merupakan toko yang sangat cocok untuk remaja-remaja saat ini yang sangat menyukai semua hal berbau tentang K-Pop terutama artisnya yang sedang marak di kalangan kita saat ini. Yeobo sendiri merupahan bahasa korea yang artinya sayang dengan membuat nama nya menjadi Yeobo store penulis berharap toko ini banyak diminati dan disayangi oleh banyak konsumen.

Dengan maraknya Kpop di Indonesia mempermudah pasar kita untuk promosi secara gencar dan terus menerus dan ini benar-benar bisnis usaha yang prosperk kedepannya juga sangat bagus. Toko Yeobo menawarkan harga miring dan diskon tertentu untuk para konsumen yang ingin bergabung menjadi reseller kami, hanya dengan modal sedikit tapi reseller apabila giat dalam berjualan pasti akan merauk untung yang sangat fantastis apabila dia tekun menjalani bisnis Kpop ini.

\section{Deskripsi Usaha}

Yeobo strore adalah usaha yang bergerak dalam bidang merchandise Idol yang biasa disebut (K-Pop) Konsep Bisnis Toko ini adalah toko baru yang didasarkan kepada hal-hal yang berbau dengan ala artis korea dengan beragam tema, baik artis, boysband maupun girlsband. Yeobo store ini nantinya akan membuka pertama kali dengan menyewa tempat sekitar $4 \times 5 \mathrm{~m} 2$ di design dengan konsep korea di Jl.Air dingin sehingga dekat dengan kampus dan masyarakat. Waktu dan jadwal operasi store akan dibuka setiap harinya kecuali hari minggu dilakkukan di cfd.

Produk adalah segala sesuatu yang dapat ditawarkan untuk memuaskan kebutuhan dan keinginan konsumen. Produk yang ditawarkan jenisnya berbeda-beda dan bervariasi, menyesuaikan selera atau keinginan dari konsumen. Antara lain :

1. Album setiap fandom (Exo, Nct127, Mx, Svt, Bts, dll)

2. Lightstik setiap fandom (Exo, Nct127, Svt, Mx, Bts, dll)

3. perintilan setiap fandom (Exo, Nct127, Svt, Mx, Bts, dll)

Berikut adalah 4 Elemen utama yang ditawarkan oleh Yeobo store yang membedakan dengan toko-toko lain pada umumnya :

1. Produk yang menyangkut hal tentang korea dan di design sendiri Yeobo store ini dididrikan dengan mengusung tema dan design yang sesuai dengan kebudayaan asli dari negara ginseng yaitu bangsa Korea Selatan.

2. Lebih menawarkan barang-barang yang mengusung tema artis korea yang sedang banyak dikagumi.

3. Membuat id card yang berfungsi mendapat potongan harga pada barang-barang tertentu dan saat mengadakan event. 
4. Metode pemasaran yang menarik. Metode pemasaran yang menarik disini adalah Yeobo store akan hadir setiap hari minggu pada kegiatan car free day (CFD) .

\section{Analisis SWOT}

Perkembangan dunia usaha saat ini mengalami perkembangan yang sangat pesat, serta tingkat persaingan yang semakin ketat, dengan memunculkan produk-produk yang baru dan dengan tujuan yang sama yang ingin memperoleh keuntungan serta menciptakan produk dengan ciri khas dan memiliki kualitas yang baik dari pesaing yang lain. Maka dari itu perlu dilakukan nya analisis untuk menentukan apakah usaha yang dilakukan layak atau tidak dari segi bisnis. Dari pernyataan tersebut lah makanya dibutuhkan Analisis SWOT. Analisis SWOT ini merupakan perencanaan strategis yang digunakan untuk mengevaluasi kekuatan (strength), kelemahan (weakness), peluang(oppurtunities) serta ancaman(threat) suatu proyek atau spekulasi bisnis.

1. Faktor Internal (kekuatan dan kelemahan)

Faktor internal adalah faktor yang berasal dari dalam,dan faktor terebutmemiliki kekuatan dan kelemahan. Adapun faktor-faktor tersebut adalahsebagai berikut;

a) Strenght (kekuatan).

Adapun kekuatan dari bisnis ini ialah:

1) Bisnis dilakukan secara online maupun offline sehingga memudahkan pelanggan menbeli walau jarak jauh.

2) Kualitas produk yang terjamin keasliannya jika official bisa dilihat dari scan barkot yang tertera.

3) Respon penjual yang cepat,ramah serta memberikan edukasi sehingga membuat pelanggan nyaman berada di store kita.

4) Memiliki keunikan di setiap barang yag di produksi langsung oleh Yeobo store.

5) Membuat id card yang berfungsi mendapat potongan harga 5\% pada barang-barang tertentu dan saat mengadakan event.

6) Memiliki ciri khas produk packingan yang menarik minat konsumen.

b) Kelemahan (weakness)

Adapun kelemahan dari bisnis ini yaitu:

1) Barang yang official biasanya sejak dikirim dari korea hingga ke toko biasannya memerlukan waktu yang lama kurang lebih 2 minggu.

2) Biaya ongkir EMS tergolong mahal.

2. Faktor eksternal (peluang dan ancaman )

Faktor eksternal atau bisa juga disebut dengan faktor dari luar, ini merupakan faktor dari luar entitas, dimana faktor ini tidak secara langsung terlibat pada apa yang sedang diteliti yang terdiri dari dua 
faktor yaitu peluang(oppurtunities) dan ancaman (threat). Adanya peluang dan ancaman ini tentunya akan memberikan data pada hasil penelitian yang akan menghasilkan startegi yang akan dihadapi.

\section{a) Peluang (opportunities)}

Adapun peluang dari binis ini yaitu:

1) Membantu customer berbelanja barang impor tanpa harus ke negaranya (korea).

2) Lokasi yang stratergis dekat dengan masyarakat kampus dan juga sekolah.

3) K-POP adalah tren yang sedang hangat di masyarakat.

b) Ancaman (threats)

Adapun ancaman yang akan mucul yaitu:

1) Adanya pesaing baru dengan usaha yang sama.

2) Munculnya pesain baru dengan memberi harga yang lebih murah dengan kualitas yang sama serta lebih berpengalaman.

3) Maraknya scammer dari seller tertentu.

\subsection{Aspek Pemasaran}

1. Beberapa aspek dalam pemasaran Segementasi, Targetting, and Positioning.

a. Segmentasi

Segmentasi geografis Yeobo store berda di Pekan Baru di jalan Kaharuddin Nasution gang Air Dingin, di mana daerah ini terbilang cukup ramai dan padat serta didukung pula oleh lingkungan yang dekat dengan salah satu Universitas dan akan sering di lewati oleh mahasiswa. Segmentasi demografi Yeobo Store lebih menjuru kepada penggemar dari aktor, boyband, girlband dan industri musik dan film Korea. Dari remaja, dewasa, hingga tua sekalipun, dari perempuan (fangirl) maupun laki-laki (fanboy) serta memiliki penghasilan menengah sampai tinggi. Segmentasi psikografis Yeobo store berdasarkan gaya hidup yang cenderung ingin "sama" stylenya dengan idolnya,dan dari kalangan remaja sampai dengan mahasiswa yang biasanya tergolong K-Popers (penggemar K-Pop). Dan pada segmentasi perilaku Yeobo store dapat ditempatkan di mana remaja hingga mahasiswa ingin terlihat "sama" penampilannya dengan sang idola, baik itu dari segi berpakaian, berbicara, barang dll.

b. Targeting.

Pangsa pasar Yeobo store ini tertuju kepada kaum millennial terutama k-popers mulai dari anak sekolah menengah pertama,sekolah menengah atas sampai yang sudah kuliah. 
Bahkan yang sudah kerja dan berumah tangga. Harapanya tingkat pembelian konsumen tinggi. Selain itu juga diharpkan sekitar $75 \%$ pembelian yang dilakukan melalui online.

c. Positioning.

Posisi pasar Yeobo store yang berlokasi di di jalan Kaharuddin Nasution gang Air Dingin kota pekan baru ini dipilih sebagai tempat berdirinya usaha ini karena kurangnya pesaing sehingga dapat menguasai pangsa pasar dan menjadi satusatunya tujuan K-Popers khususnya yang berdomisili Pekanbaru dan sekitarnya. Hal ini karena ditinjau dari pelanggan yang tidak perlu bingung dan jauh-jauh apabila ingin berbelanja K-Pop merchandise, terlebih lagi target pasar kami adalah remaja hingga mahasiswa yang cenderung malas bepergian jarak jauh hanya untuk membeli 1-5 barang.

2. Perkiraan permintaan dan penawaran

a. Permintaan.

Permintaan K-Pop merchandise biasanya sangat mengalami peningkatan di saat adanya perilisan barang baru oleh agensi artis, diselenggarakannya konser. Di luar keadaan di atas, untuk meningkatkan permintaan kami akan membagikan kuisioner untuk melihat seberapa antusias pelanggan akan barang yang kami tawarkan bahkan barang apa saja yang harusnya diperbanyak persediaannya, tak hanya itu kami akan menggunakan cara sampling/tester sehingga pelanggan bisa membuktikan sendiri keaslian barang (apabila barang yang bersifat official Cara membuktikannya dengan menyamakan produk dengan produk yang ada di website resmi agensi.

b. Penawaran

Tingkat penawaran akan semakin tinggi apabila target melakukan permintaan yang tinggi pula. Seperti pada saat barang tersebut baru dirilis, menjadi trending topic, atau sekedar mengoleksi saja.

3. Strategi Pemasaran Perusahaan terhadap Pesaing

a. Product.

Produk adalah segala sesuatu yang dapat ditawarkan untuk memuaskan kebutuhan dan keinginan konsumen. Produk yang ditawarkan jenisnya berbeda-beda dan bervariasi, menyesuaikan selera atau keinginan dari konsumen. Antara lain :

1. Album setiap fandom (Exo, Nct127, Mx, Svt, Bts, dll)

2. Lightstik setiap fandom (Exo, Nct127, Svt, Mx, Bts, dll)

3. perintilan setiap fandom (Exo, Nct127, Svt, Mx, Bts, dll) 


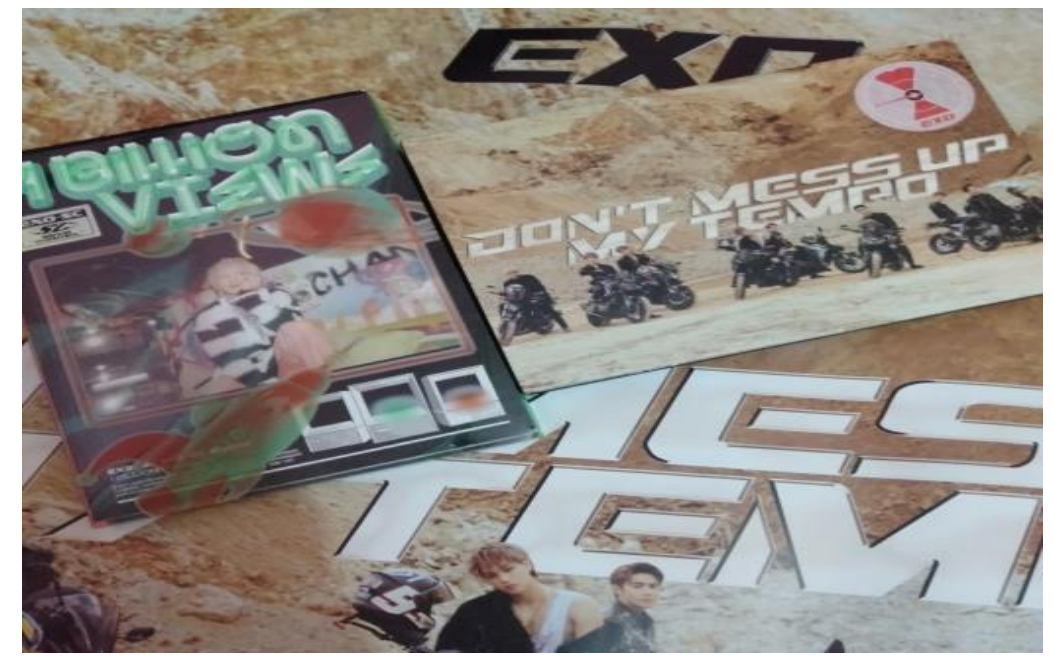

Gambar 1 Album dan poster exo

(sumber: Yeobo store)

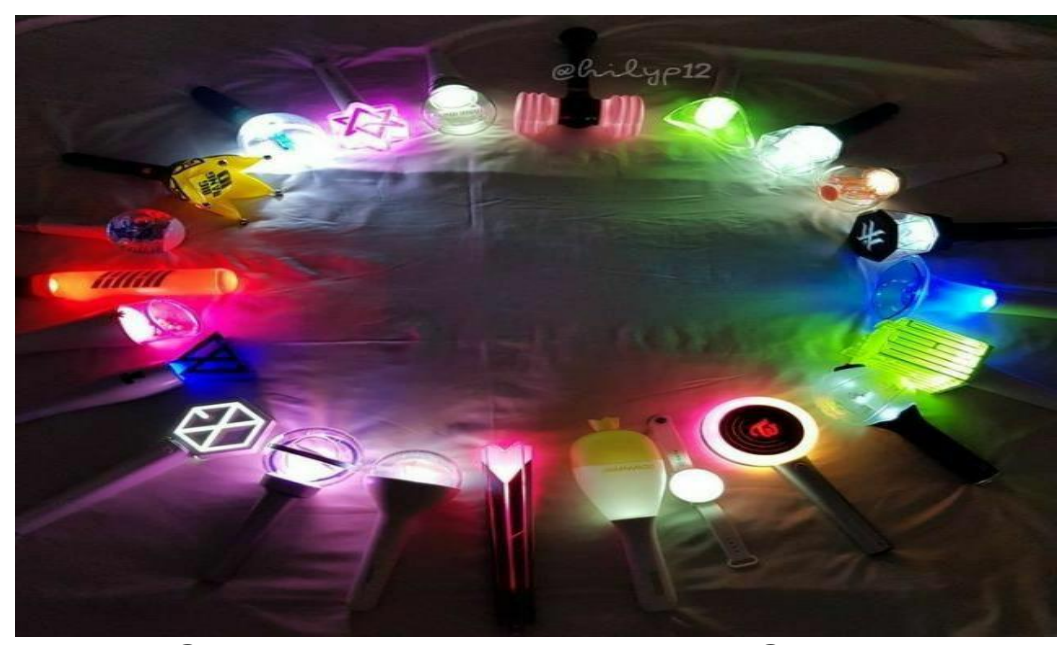

Gambar 2 lighstic Boygrup and Girlgrup

(Sumber : Pinterest)

b. Price.

Untuk harga Album dan Merchandise Yeobo Store memiliki berbagai paketan baik dari skala pembelian satuan, maupun puluhan. Semakin banyak pembelian semakin banyak diskon yang akan didapatkan.

Tabel 1 harga jual barang official

\begin{tabular}{|c|c|c|c|}
\hline No. & Jenis Barang & Harga & Rincian \\
\hline 1 & Lighstick & Rp. 600.000/pcs & \multirow{3}{*}{$\begin{array}{l}\text { Exclude: } \\
\text { EMS dan Ongkir } \\
\text { ke alamat } \\
\text { customer. }\end{array}$} \\
\hline 2 & Doll(boneka) & RP. 400.000/pcs & \\
\hline 3 & Album & Rp. 280.000/pcs & \\
\hline
\end{tabular}




\begin{tabular}{|c|c|c|}
\hline 4 & Bracelet & Rp. $100.000 /$ pcs \\
\hline 5 & Photobook & Rp. 500.000/pcs \\
\hline
\end{tabular}

Tabel 2 harga jual barang non official

\begin{tabular}{|c|l|l|l|}
\hline No. & \multicolumn{1}{|c|}{ Jenis Barang } & \multicolumn{1}{c|}{ Harga } & \multicolumn{1}{|c|}{ Keterangan } \\
\hline 1 & T-shirt & Rp. $100.000 /$ pcs & Exclude: \\
\hline 2 & Gelang & Rp. $25.000 /$ pcs & EMS dan Ongkir ke \\
\hline 3 & Stiker & Rp. $5.000 /$ pcs & alamat customer. \\
\hline 4 & Poster & Rp. $10.000 /$ pcs & \\
\hline
\end{tabular}

c. Promotion

- Social Network

Untuk mempromosikan barangbarang, K-Pop merchandise store akan menggunakan media social seperti Instagram, Line, dan Twitter,facebook. Selain sebagai media promosi, digunakannya media sosial juga untuk media testimoni bagi pelanggan.

- Brosur

Pembagian brosur akan dibagikan di sekitar jalan Rawamangun dan akan di fokuskan pembagian brosur di lingkungan kampus sekitar jalan Rawamangun.

- Event.

Yeobo store akan mendirikan stand/booth di setiap sudut tempat pada saat diselenggarakan konser, bazar, dan event lainnya.

Promosi untuk setiap pembelian 1 set album cd (semua version) akan mendapatkan harga khusus. Selain itu, merchandise "Yeobo store" juga menawarkan produknya ke stan bazaar dan acara gathering kpopers sebagai upaya melebarkan sayapnya dan meningkatkan penjualan. Karna pada dasarnya kalangan tersebut membeli dalam skala yang cukup besar dan berkelanjutan.

4. Operasional.

a. Proses produksi

Produk yang saya jual ini diproduksi dan didistribusikan langsung dari Korea Selatan dan juga meminta barang dari supplier yang sudah terkenal dan terjamin atas kualias barangnya. 


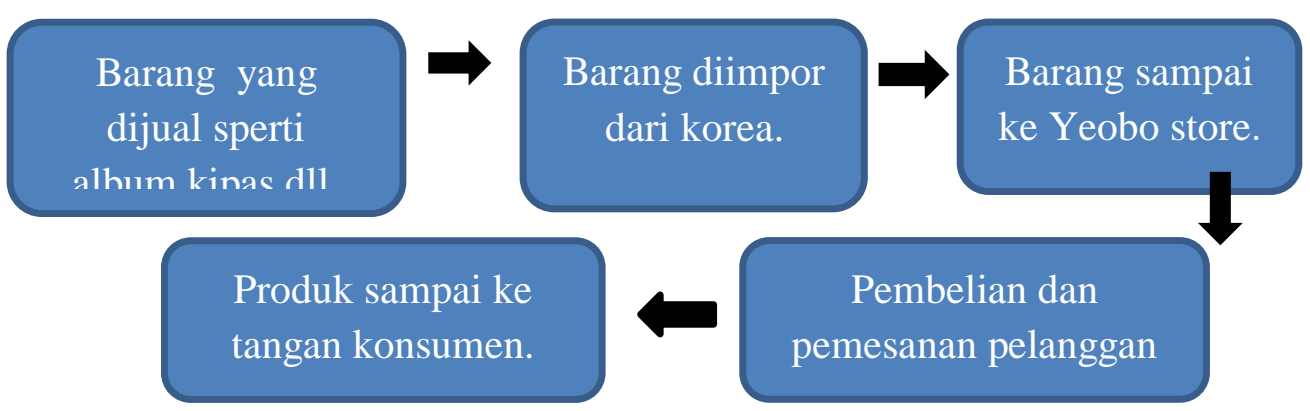

Gambar 3 proses urutan produksi

Yeobo Store mempersiapkan produk - produk pada masingmasing kualitas barang, dengan proses produksi yang baik akan mendapatkan hasil yang baik juga. Produksi Korea Marchandise Store dilakukan dengan mengimpor barang dari negara korea untuk mendapatkan kualitas barang yang berkualitas, kemudian dipasarkan di Korea Marchandise Store.

b. Sumber-Sumber Produk

Sumber-sumber untuk produk saya ini, saya dapatkan dari supplier ternama dan terpercaya di Indonesia. Supplier ini mengambil dan menjual produk-produknya langsung dari Korea Selatan. Saya menjamin bahwa produk yang saya jual

\subsection{Aspek Keuangan} merupakan $\mathrm{p}$ roduk original.

Berikut ini adalah rincian biaya produksi "Yeobo store":

\begin{tabular}{|c|l|c|l|l|}
\hline No. & Nama Barang & $\begin{array}{c}\text { Jumlah } \\
\text { Barang }\end{array}$ & $\begin{array}{c}\text { Harga } \\
\text { Satuan }\end{array}$ & Jumlah \\
\hline 1 & Album & 10 & Rp.230.000 & Rp.2.300.000 \\
\hline 2 & Lighstick & 8 & Rp.500.000 & Rp. 4.000 .000 \\
\hline 3 & Poster & 50 & Rp. 5000 & Rp. 250.000 \\
\hline 4 & Stiker unoff & 40 & Rp.7000 & Rp. 280.000 \\
\hline 5 & Kipas unoff & 30 & Rp.8000 & Rp. 240.000 \\
\hline 6 & $\begin{array}{l}\text { Biaya } \\
\text { pengiriman }\end{array}$ & & & Rp.8000 \\
\hline 7 & Biaya packing & & & Rp. 12000 \\
\hline 8 & Biaya lain-lain & & & Rp. 7.115 .000 \\
\hline MODAL AWAL & & & \\
\hline
\end{tabular}


Berikut ini adalah rincian proyeksi pendapatan "Yeobo store":

\begin{tabular}{|c|l|c|c|l|}
\hline No & $\begin{array}{c}\text { Nama } \\
\text { Barang }\end{array}$ & $\begin{array}{c}\text { Jumlah } \\
\text { barang }\end{array}$ & $\begin{array}{c}\text { Harga } \\
\text { barang }\end{array}$ & \multicolumn{1}{|c|}{ Jumlah } \\
\hline 1 & Album & 10 & Rp.280.000 & $\begin{array}{l}\text { Rp. } \\
2.800 .000\end{array}$ \\
\hline 2 & Lighstick & 8 & Rp.600.000 & $\begin{array}{l}\text { Rp. } \\
4.800 .000\end{array}$ \\
\hline 3 & Poster unoff & 50 & Rp.10.000 & Rp. 500.000 \\
\hline 4 & Stiker unoff & 40 & Rp.15.000 & Rp. 600.000 \\
\hline 5 & Kipas unoff & 15 & Rp.15.000 & Rp. 450.000 \\
\hline \multicolumn{2}{|l|}{ Total Pendapatan } & & & $\begin{array}{l}\text { Rp. } \\
9.150 .000\end{array}$ \\
\hline
\end{tabular}

Analisa Keuntungan Break Even Point (BEP) adalah harga ditentukan bedasarkan titik impas (Purwana, Hidayat 2016). Berikut di bawah ini merupakan rumus perhitungan BEP pada usaha Yeobo Store menurut Hidayat Purwana, Buku Studi Kelayakan Bisnis:

Berikut ini adalah rincian keuntungan "Yeobo store".

1). Keuntungan $=$ Total pendapatan - modal awal

$$
\begin{aligned}
& =\text { Rp. } 9.150 .000-\text { Rp. } 7.115 .000 \\
& =\text { Rp. } 2.035 .000
\end{aligned}
$$

\subsection{Aspek Organisasi dan Manejemen}

Berikut ini merupakan struktur organisasi yang direncanakan oleh Yeobo Store:

1. Nama Usaha : Yeobo Store

2. Jenis usaha : Industri Dagang(menjual barang-barang k-pop.

3. Alamat usaha : Jl. Kaharuddin Nasution ,Air dingin kota Pekanbaru.

4. Nama Pemilik : Anita

5. Status Pemilik di Usaha : Pemilik

\subsection{Pespektif Masa Depan usaha}

Dengan terciptanya usaha dibidang perdagangan khususnya di bidang merchandise K-Pop dengan lokasi yang strategis serta memiliki keunggulan-keunggulan dari pesaing yang lain ,maka kami yakin usaha ini akan maju. Kami juga melihat potensi dalam bisnis ini dari unsur keunggulan pasar , sebab lima tahun terakhir ini K-Pop sangat mendunia hingga menjadi globalisasi budaya termasuk di Indonesia sendiri. Kegandrungan akan musik K-Pop membawa dampak tersendiri bagi penggemarnya sehingga banyak pihak menjadikan ini sebagai peluang bisnis yang sangat besar baik dibidang Fashion,Kecantikan maupun Industrial. Maka kami yakin usaha ini akan maju dan berkembang sehingga mampu bersaing 
dengan pesaing lain baik nasional maupun internasional dimana tempat penjualan merchandise aslinya yaitu Korea.

\section{Kesimpulan}

Demikianlah proposal usaha yang kami susun dengan semaksimal mungkin. Tidak lupa kami mengucapkan banyak terimakasih kepada semua pihak yang telah mendukung dalam penyelesaian proposal usaha ini. Kami menyadari bajwa proposal usaha kami jauh dari kesempurnaan. Untul itu kami harapkan kritik saran dari pembaca yang bersifat membangun .

Semoga proposal usaha ini dapat bermanfaat dan usaha kami dapat berjalan sesuai rencana yang kami tuangkan disini. Akhirnya,apabila terdapat kesalahan dan kekurangan pada proposal ini,kami mohon maaf sebesar-besarnya.

\section{DAFTAR PUSTAKA}

Veronika, Maria. 2018. "Eksploitasi Loyalitas Penggemar Dalam Pembelian Album K-Pop." Koneksi 2 No 2:433-40.

Fadiati, A.\& Purwana, D. 2011. Menjadi Wirausaha Sukses. 1st ed. Bandung: Remaja Rosdakarya.

Purwana, D., Hidayat, N. 2016. Studi Kelayakan Bisnis. 1st ed. Jakarta: Rajawali.

Purwana, D., Hasan., M. 2017. Pengantar Ilmu Organisasi. 1st ed. Bogor: In Media.

Agustiani, Hendriati. 2002. "Perkembangan Remaja Menurut Pendekatan Ekologi Serta Hubungannya Dengan Konsep Diri Dan Penyesuaian Diri Pada Remaja." Vol.9.No.1.

Nuryanto., Oktaviani, Femi. 2020. "Pemanfaatan Instagram Sebagai Media Komunikasi Komunitas KPOP." 2,No 1:239-48. Kartika, V. C. (2018). Gaya Hidup Penggemar EXO di Surabaya Terhadap Produk Merchandise Boyband EXO.

Purwana, d., Wibowo, A. 2017. Pendidikan Kewirausahaan Di Perguruan Tinggi. 1st ed. Yogyakarta: Pustaka Belajar.

Sulaiman., Dwi, Ririn. 2020. "Analisis Strategi Pemasaran Dalam Meningkatkan Volume Penjualan." Vol6,No1:2442-3343.

Sumarwan, Ujang. 2011. Perilaku Konsumen Teori Dan Penerapannya Dalam Pemasaran. 2nd ed. Jakarta: PT.Ghalia Indonsia.

Lastriani, Usman. 2018. "Interaksi Dunia Maya Antar Penggemar Boyband EXO." Etnografi Indonesia Vol 3,No 1. 